\title{
Hatay İli Sağlık Bakanlığı Hastanelerinin Finansal Performanslarının Değerlendirilmesi*
}

\author{
Songül KAKİLLİ ACARAVCI ${ }^{1}$
}

Mehmet GAZİ ${ }^{2}$

ÖZ: Hatay İli Sağlık Bakanlığ hastanelerinin 2008-2017 yılları arasında finansal performansları oran analizi yöntemi kullanılarak ölçülmüştür. Çalışmanın evrenini Hatay Büyükşehir Belediyesi sinırları içerisindeki İl Sağglı Müdürlüğ̈̈ne bağlı toplamda 9 hastane oluşturmaktadır. Oran analizi yöntemi kullanilarak, evrendeki kamu hastanelerinin kamu hastane birliklerine bağlanılmadan önceki ve bağlanıldlktan sonraki finansal performansları yıllar itibariyle analiz edilmeye çalışllmıştır. Hastanelerin likidite, faaliyet, mali yapı ve karlılık durumlarını gösteren 21 oran anahtar finansal oran olarak değerlendirilmeye alınmıştır. Elde edilen bulgulara göre; hastanelerin likit varlıklarının yetersizliği, kısa vadeli yabancı kaynak kullanımının arttı̆̆l, stoklarının fazlalı̆̆ ve hastanelerin zarar eğiliminde olduklar görülmektedir. Bu çalışmanın sağllk yönetiminde bulunanlara planlama ve politika geliştirmelerinde önemli ipuçları sağlayacağı düşünülmektedir.

Anahtar Kelimeler: Performans, Finansal Tablolar, Oran Analizi, Hastaneler

Jel Kodu: M2, M4

\section{Evaluation of Financial Performance of Hatay Ministry of Health Hospitals}

\begin{abstract}
Financial performance of Hatay provincial health department hospitals in 20082017 was measured by using ratio analysis method. The universe of the study consists of nine hospitals connected to the provincial health directorate within the borders of Hatay Metropolitan Municipality. Using the ratio analysis method, it is tried to analyze the financial status of public hospitals in the universe by years before not connecting and after connecting to public hospital associations. Twenty-one proportion of the hospitals' liquidity, operating, financial structure, and profitability status are considered as key financial ratios. According to results of the ratio analysis; hospitals lack of liquid assets, increased use of short-term liabilities, excess stocks, and hospitals trends to loss. It is thought that this study will provide important clues to health management actors in planning and policy development.
\end{abstract}

Keywords: Performance, Financial Statements, Ratio Analysis, Hospitals Jel Codes: M2, M4

\footnotetext{
*Bu çalışma Mehmet Gazi’nin “Hatay İli Sağlık Bakanlı̆̆g Hastanelerinin Finansal Performanslarının Değerlendirilmesi”" başlıklı yüksek lisans tezinden yararlanılarak hazırlanmıştır. ${ }^{1}$ Prof. Dr., Hatay Mustafa Kemal Üniversitesi, İktisadi ve İdari Bilimler Fakültesi, İşletme Bölümü, sacaravci@mku.edu.tr, orcid.org/0000-0002-1359-5483.

2 Hatay İl Sağlık Müdürlüğü, Bütçe ve Muhasebe Uygulamaları, mehmetgazi2@saglik.gov.tr, orcid.org/0000-0003-4469-3323.
} 


\section{Giriș}

Türkiye'nin en büyük sağlık hizmet sunumunu gerçekleştiren Sağlık Bakanlığı hastanelerinin çok fazla kaynak kullanım oranına sahip olması kamu yönetiminin önemli bir parçasını oluşturmasını sağlamaktadır. Ekonomik bir şekilde sahip olduğu kaynakları verimlilik düzeyinde kullanarak etkin hizmet sunumuna dönüştürebilmeleri önemlidir. Kamu hastanelerinin birincil amaçları arasında, sağlık hizmeti üretmek ve sunmak olsa da sürdürülebilir olması hatta sektörde rekabet edebilme düzeyine gelebilmeleri için hizmet kalitesini yükseltme eğilimi göstermeleri gerektiğinden, finansal performanslarına dikkat etmelidirler. Finansal performanslarına etki edecek en önemli çevreler olarak; finansman sağlayıcı görevindeki ödeyici kuruluşlar, tedarikçi firmalar, hastalar, hasta yakınları ve çalışanlardır. Her bir çevrede yaşanan olumsuz bir etkileşim finansal performansa etki edebilmektedir.

Girdiler ile katlanılan maliyetlerin, giderler ile çıktıların getirisi finansal performansa ne ölçüde katkı sağladığının tespitinin yapılması önem arz etmektedir. Sağlık Bakanlığı hastanelerinin performanslarının analizi ve analiz sonuçlarına göre yapılması gereken iyileştirmelerin tespiti, kaynakların verimli ve etkili kullanımı için önemlidir.

$\mathrm{Bu}$ çalışmada Hatay İli genelindeki Sağlık Bakanlığı hastanelerinin finansal performanslarının değerlendirilmesi oran analizi yöntemi ile incelenmiştir. Analizde bilanço kalemleri ile gelir tabloları kalemlerinin oranlanması esasına dayandırılarak karlılık, verimlilik ve ekonomiklik hakkında bilgiler sağlanmıştır.

Çalışma dört bölümden oluşmaktadır. Çalışmanın ilk bölümünde literatüre yer verilmiştir. İkinci bölümde araştırmanın evreni, örneklemi ve yöntemi anlatılmıştır. Üçüncü bölümde bulgular yer almış olup, son olarak çalışmanın sonuçları değerlendirildikten sonra hastanelerin sorun yaşadığ 1 konularda öneriler geliştirilmiştir.

\section{Literatür}

Hastanelerin finansal performanslarının değerlendirilmesi için yapılan oran analizleri sonucunda literatürde elde edilen bulgular aşağıda yer almaktadır.

Likidite Oranları: Cari oran ile ilgili olarak; Alparslan (2014) Sağlık Bakanlığı Ankara il merkezi hastanelerinin 2008-2012 yıllarını kapsayan cari oranın, yıllar itibariyle düşüş sergilediğini, 2010 yılında 2'nin altına düştüğünü ve 2012 yılında 1,03 değerinde olduğunu belirtmiştir. Gazi vd. (2016) 2008-2015 yıllarını baz alarak Kamu Hastane Birlikleri’ne geçiş öncesi ve sonrası 89 Kamu Hastane Birliği'ne bağlı 829 hastanenin finansal performanslarını analiz etmişlerdir. Elde edilen bulgulara göre 2008 yılından 2015 yılına kadar cari oranın sürekli bir azalış eğiliminde olduğu ve 2015 yılında bu oranın 0,54 değerine kadar gerilediği vurgulanmıştır. Koçyiğit ve Kocakoç (2019), Ankara İlinde 2008-2017 yıllarını kapsayan 13 devlet hastanesi ve 13 eğitim ve araştırma hastanesinin cari oranlarında 
2008 yılından 2017 yılana dek düşüş yaşandığını hatta kamu hastaneleri birliği döneminde bu düşüşün hızlandığını belirtmişlerdir.

Likidite oranı ile ilgili olarak; Orak (2015), Ankara'daki Sağlık Bakanlığı'na bağlı 13 eğitim ve araştırma ve 7 devlet hastanesine ait 2008-2013 yıllarını kapsayan çalışmasında, bu oranın 2009 yılında devlet hastanelerinde 1,46'lık değeriyle standartlara uygun seyrederken, bu ylldan sonra her iki hastane türünün de standart oranın altında kaldığını, hastanelerin likidite sıkıntısı yaşadıklarını ve 2010 yılından itibaren stoklara olan bağımlılığın arttığını, kısa vadeli borçları ödeme gücünün azaldığını belirtmiştir. Güney ve Korkmaz (2013), İstanbul'da bir eğitim ve araştırma hastanesinde 2005-2008 yılları arasında bu oranın standardın altında düşüş eğiliminde olduğunu belirtmektedir. Palamutçu (2013) bir kamu hastanesi ve bir özel hastanesinin 2008-2011 yıllarında likidite oranının standart oranın altında kaldığı, borçlarının tamamının dönen varlıklarla ödenemeyeceğini ve stoklara bağlı kalındığını tespit etmiştir. Ateş'in (2014) 2011-2012 yıllarını kapsayan çalışmasının bulgularına göre likidite oranı 2011 yılında 0,796 ve 2012 yılında 0,47 olarak gerçekleşmiştir. Eğitim ve araştırma hastanelerinde bu oranın diğer devlet hastanelerine göre daha düşük çıkmasının temelinde; teşhis ve tedavi sürecinde gerekli olan ilaç ve tıbbı malzemelerin bulundurulması olarak belirtilmiştir. Koçyiğit ve Kocakoç (2019) bu oranın cari oran gibi 2008 yılından 2017 yılına dek düştügünü ve kamu hastanelerinin kamu hastane birliğine bağlandıktan sonra bu düşüşün hızlandığını vurgulamıştır.

Nakit oranı ile ilgili olarak; Pay (2017) çalışmasında Sağlık Bakanlığı'na bağlı 3 ilçe hastanesinin 2010-2015 yıllarını kapsayan verilerle Kamu Hastaneleri Birliği öncesi ve sonrası finansal performans değerlendirmesinde bulunmuştur. 2014 ve 2015 yıllarında bir hastanenin cari oranının standart oranın üstünde görüldüğü, diğer hastanelerin tüm değerlerinin standart oranın altında görüldüğü ve bu yıllar hariç olarak hastanelerin stoklarını paraya dönüştürememesi ve alacaklarını tahsil edememesi sonucu kısa vadeli borçlarını ödemede problemlerle karşılaşılmış olabileceği vurgulanmaktadır. Bülüç vd. (2017), Borsa İstanbul'da işlem gören özel bir hastanenin nakit oranının 2013 ile 2016 yıllarında standart oranın çok altında değer aldığını tespit etmişlerdir. Gazi vd. (2016) 2008-2015 yılları arasında nakit oranının 0,20 değerinden 0,17 değerine düştüğünü belirtmişlerdir. Islıcık (2018) 2014-2016 yılları arasında çeşitli il ve ilçelerde faaliyet gösteren 203 kamu hastanesi kapsamında finansal performans analizi yapmıştır. Analiz sonucunda 2015 yılı itibariyle hastanelerin nakit oranlarında düşüş olduğunu ve nakit sıkıntısı yaşandığını vurgulamıştır.

Mali Yapı Oranları: Finansal kaldıraç oranı ile ilgili olarak; Orak (2015) bu oranın 2008 yılında 0,22 iken yıllar itibariyle artış gösterdiğini ve 2013 yılında 1,19'a kadar yükseldiğini tespit etmiştir. Islıcık (2018) finansal kaldıraç oranının 2014, 2015 ve 2016 yıllarında sirasıyla $0,71,1,09$ ve 2,31 değerlerinde olduğunu ve hastanelerin bu yıllarda finansal risklerinin yüksek olduğunu vurgulamıştır. Çam (2008) Karaman Devlet Hastanesi’nin 2003-2007 yıllarını kapsayan çalışmasında, 
2003 y1lında bu oranın 0,09'dan 2004 yılında 0,20'ye yükseldiğini, diğer y1llarda \%20 seviyelerinde devam ettiğini ve bu artışın en büyük sebeplerinin "Ödenecek Döner Sermaye Yükümlülükleri” kaleminde artışların olduğunu ayrıca hastanelerin çoğu ihtiyaçlarını kendi satın alma birimleri ile gerçekleştirmeye başlamasıyla birlikte ticari borçlarda artışlar meydana geldiğini belirtmiştir. Gazi vd. (2016) 2008 ve 2011 yılları arasında hastanelerin henüz Kamu Hastane Birliklerine bağlanmadan önce bu oranın, normal kabul edilen standart orana yakın iken; hastanelerin Kamu Hastane Birliklerine bağlandıktan sonra bu oranın keskin bir şekilde yükseldiğini ve 2015 yılına kadar devam ettiğini belirtmişlerdir. Koçyiğit ve Kocakoç (2019) finansal kaldıraç oranının Eğitim ve Araştırma Hastanelerinde ve Devlet Hastanelerinde 2008 yılında 0,40 civarlarında seyrederken 5,59 değerine kadar yükseliş göstermiş olup kamu hastane birliklerine bağlandıktan sonra bu yükselişin hızlandığı ve risk göstergesi olan bu oranın yıllar içinde artmasının, işletmenin anapara borç taksitlerini ve faizlerini ödeyememe riskini de beraberinde getirerek risk seviyesini yükselttiğini vurgulamışlardır.

Toplam borçlar/özkaynaklar oranı ile ilgili olarak; Karadeniz (2016) 2011-2013 yıllarını kapsayan çalışmasında, hastanelerde yabancı kaynakların özkaynakların yaklaşık 2 katı olduğunu ve bunun nedeni olarak yabancı kaynak baskısı ve faiz yükünün olduğu vurgulanmıştır. Aydemir (2018) 2013-2015 yıllarını kapsayan çalışmasında, yabancı kaynakların özkaynakların 3 katını aşan seviyede gerçekleştiğini söylemektedir.

Faaliyet Oranları: Stokların etkili kullanımı ve devir hızının fazla olması tüm işletmeler için olumlu bir durumdur. Özel hastaneler üzerine Bıçakçı vd. (2018) tarafından yapılan 2009/2013 yıllarını kapsayan çalışmada, bu oranın Türkiye ortalaması 4,89 ile 5,98 oranında değişmektedir. Bülüç vd. (2017) özel hastanelerin 2013-2016 yıllarını kapsayan bu oranın, 14,78 ile 28,58 arasında dengeli bir artış gösterdiğini belirtmişlerdir. Karadeniz (2016) 2011 ve 2013 yılları arasında stok devir hızının 23'ten 18'e düşmesini, hastanelerin ağırlık olarak hizmet üreten işletmeleri olduğunu ve hizmetleri stoklama imkanı olmadığından hastanelerin stoklayabileceği ürün miktarlarının az olması ve dolayısıyla bu konjonktürde 7-10 günlük stok ile faaliyetlerini sürdürmesinin yeterli olacağını vurgulamaktadır. Pay'ın (2017) çalışmasında 2010 yılında en düşük stok devir hızı oranının 3,27 olması, hastanenin yeni açılması nedenine bağlı olduğunu ve 2015 yılına doğru 50 seviyelerinde bir artış trendine girdiği vurgulanmıştır. Alparslan'ın (2014) çalışmasında 2008 yılında stok devir hızının 54,45 iken, 2009 y1lında 19,91'e düştüğü ve 2010 yılında tekrar artış trendine girerek 43,18 olduğu tespit edilmiştir. Buna göre hastanelerin stoklarının fazla olmasından stok bulundurma maliyetlerine katlanmak zorunda oldukları ve nakit paranın stoklara yatırıldığı belirtilmiştir. Avcı (2014) ise sağlık sektöründe bu oranın ortalamasının 50 olduğunu ve 2005-2011 yılları arasında bu oranın 15'in üzerine çıkmadığını belirtmiştir. Stok devir hızının yüksek olması hastanenin girdilerinin fazla olduğu, dolayısıyla hastanenin tüm hizmet birimlerinin faaliyetlerinin yoğunluğuna işaret etmektedir. 
Özkaynak devir hızı ile ilgili olarak; Alparslan (2014) 2008 ile 2012 yılları arasında bu oranın pozitif değerde olmasının özkaynakların verimli kullanıldığını, 2010 yılında ise geçmiş yıl zararları sebebiyle bu oranın -3,29'a düştügünü vurgulamıştır. Islıcık (2018) 2014 yılında araştırma kapsamındaki hastanelerin ortalamasını 37,88 bulmuştur. 2015 ve 2016 yıllarında özkaynak yetersizliği nedeniyle bu oranın negatif değerler aldığını vurgulamıştır. Özkaynak devir hızının çok yüksek olması hastanelerin faaliyetlerini yabancı kaynaklarla finanse ettiğini gösterirken, dengeli bir özkaynak kullanımı verimliliğine işaret etmektedir. Palamutçu (2013) ise özkaynak devir hızını 2008 yılında 56,29, 2009 yılında -43,54, 2010 yılında -15,52 ve 2011 yılında 97,55 olarak tespit etmiştir.

Aktif devir hızı ile ilgili; Koçyiğit ve Kocakoç (2019) bu orana ilişkin değerlerin 2008-2017 yılları arasında arttığını, kamu hastanelerinin kamu hastane birliklerine bağlanmasıyla beraber bu artışların hızlandığını, aktif kalemlerinin kapasitelerinin üstünde kullanıldığını, 2017 yılındaki yüksek düşüş değeriyle varlıklarını etkin kullanamadığını vurgulamıştır. Avcı (2014) hastane için aktif devir hızının sektör ortalamasını 0,97 olarak bulmuştur. 2005 ile 2007 yıllarında hastanenin aktif devir hızının standart oranın altında kaldığını belirtmiş ve bunu alacak tahsilinin zayıflığına bağlamıştır. 2008 ile 2011 yılları arasındaki değerlerin genel kabul oranının üstünde olmasıyla da aktiflerin verimli kullanıldığı değerlendirmesini yapmıştır. Islıcık (2018) 2014, 2015 ve 2016 yıllarında sirasıyla 6,98, 7,24 ve 8,7 değerleriyle söz konusu hastanelerin tam kapasiteyle çalıştığını belirtmiştir.

Alacakların ortalama tahsil süresi ile ilgili olarak; Gazi vd. (2016) bu oranın 2008 y1lında 91 günden 2012 ve 2013 yıllarında 24 güne kadar gerilediğini, bu durumun alacakların likiditesinin arttığının bir göstergesi olduğunu vurgulamıştır. Yine 2008 ve 2015 yılları arasında ticari borçların ödenme süresinin en yüksek 96 gün iken en düşük borç ödeme süresinin 27 gün olduğunu ve kamu hastane birliklerine geçmeden alacakların tahsil sürelerinin borçlarını ödeme sürelerinden daha yüksek olduğunu belirtmiştir. Karadeniz (2016) 2011, 2012 ve 2013 yıllarında alacakların tahsil süresini 72 gün olarak bulmuştur. Bülüç vd. (2017) bu sürenin 2013, 2014, 2015 ve 2016 yıllarında sirasıyla 65,98,70,15, 77,28 ve 66,52 gün olduğunu ve alacakların zamanında tahsil edilemediğini belirtmiştir. Çam (2008) 2003 ile 2007 yılları arasında bu sürenin 148 günden 223 güne çıktığını tespit etmiştir. Yıldız (2013) özel hastanelerin alacakların ortalama tahsil süresinin 67,04 gün iken, kamu hastanelerinin alacakların ortalama tahsil süresinin 45,92 gün olduğunu dolayısıyla alacakların tahsilatı konusunda devlet hastanelerinin politikalarının daha etkin, borçlarını ödeyebilme konusunda ise özel hastanelerden daha rahat olduklarını belirtilmiştir.

Özkaynak karlılığı oranı, birçok çalışmada finansal performans ölçütü olarak baz alınmıştır. Özgülbaş ve Bayram (2002) hastanelerin finansal performanslarının değerlendirilmesinde karlılık durumlarının tespitinde özkaynak karlılığına dikkat çekmişlerdir. Tarcan (2006) 771 kamu hastanesinin 2005 yılı özkaynak karlılığı oranını ortalama 0,43 olarak tespit etmiştir. Özgülbaş (2006), Sağlık Bakanlığı 
hastanelerinin 1996 ile 2000 yıllarını kapsayan Türkiye geneli özkaynak karlılığını ortalama 0,70 olarak tespit etmiştir. Kırbaş (2010) çalışmasında 2005-2008 yılları arasında özkaynak karlılığını ortalama olarak 0,14 olarak hesaplamıştır. Çalışkan (2015) kamu hastanesinin 2009-2013 yılları arasındaki finansal verilerini kullanılarak Du Pont Analiz tekniği uygulamış, karlılığa dayalı performansı ve performans sapmalarının nedenlerini analiz ettiği çalışmasında özkaynak karlılığı oranı ile ilgili olarak 2009 yılında 10,4, 2010 y1lında 0, 2011 yılında 14,4, 2012 yılında 18,7 ve 2013 yılında 0 değerlerini hesapladığ 1 ve 2010 yılındaki değerin hastane varlıklarının etkin kullanılmasından çok borçla finanse edildiğini vurgulamıştır. 2010 yılındaki sert yükselişin nedenini ise satışlarda meydana gelen artışlara bağlamaktadır. 2011 ile 2012 yılları arasındaki artışı net kar, aktif karlılığı ve özkaynak çarpanının artmasıyla açıklamaktadır. 2013 yılı itibariyle sert düşüş göstermesi net karın sıfır olması ile açıklanmaktadır.

Tüm bu veriler ışı ğında, araştırma kapsamındaki hastanelerin mülkiyetleri göz önünde bulundurularak farklı çalışmalarda farklı sonuçlar bulunmasının normal olarak kabul edildiği dolayısıyla öncelikli amaçlarının kar olmadığı kamu hastanelerinin yıllara göre finansal açıdan başarısızlık gösterdiği ancak kaynaklarını ve varlıklarını etkili ve verimli kullanmalarının önünde bir engel olmadığı düşünülmelidir.

Tarcan (2006) çalışmasındaki tüm hastaneler için net satış karlılı̆̆ı oranının ortalama değerini 0,16 olarak tespit etmiştir. Hastaneleri başarılı ve başarısız olarak ele alarak net satış karlılığı oranını başarılı hastaneler için 0,25; başarısız hastaneler için ise 0,08 olarak hesaplamıştır. 2010 ve 2014 yıllarında pozitif değer almasına rağmen başarısız hastaneler için nitelendirilen orana ve genel olarak yıllara göre değerlendirildiğinde hastanelerin zarar ettikleri söylenebilir. Akça ve İkinci (2014) Ankara' da bir özel hastanenin 2006-2010 yıllarını kapsayan bu oranın 2006 yılında 0,20 değerinden 2010 y1lı sonuna kadar 0,08 'e gerilediğini belirtmiştir. Akdemir ve Dayı (2013) Kastamonu İlindeki 12 kamu hastanesinin 2008-2012 döneminde net satış karlılıklarının yükselen bir trende sahip olmadıklarını, bu oranın bazı dönemlerde pozitif değer almasına rağmen hastanelerin geçmiş yıl zararlarının olması dolayısıyla karlılık durumlarının süreklilik arz etmediğini, tüm hastanelerin zarar ettiklerini ve bunun özkaynak yapılarına olumsuz etkisinden bahsetmektedirler. Bülüç vd. (2017) 2013 ile 2016 yılları arasında net satış karlılığ oranını hesaplamış ve negatif sonuç bulmamışlardır. Islıcık (2018) 203 kamu hastanesinin 2014 ile 2016 yıllarını kapsayan net satış karlılığı oranını ölçmüş ve 2014 yılındaki 0,02 değeri haricinde diğer y1llarda negatif sonuçlar tespit etmiştir.

Aktif karlılığı da performans ölçümünde kullanılan bir orandır (Özgülbaş, 2001: 74). Tarcan (2006) kamu hastanelerinin Türkiye geneli 2005 yılı aktif karlılığ1 oranını ortalama 0,25 olarak tespit etmiştir. Özgülbaş (2006) bu oranı Türkiye geneli ortalama 0,27 olarak hesaplamıştır. Alparslan (2014) aktif karlılık oranının 2008 ile 2012 yılları arasında negatif seyrettiğini tespit etmiştir. Orak (2015) 20082013 yılları arasında aktif karlılık oranının -0,66 değerine kadar düştüğünü tespit 
etmiştir. Islıcık ise (2018) 2014-2016 y1lları arasında tüm hastanelerin ortalamasını sırasıyla -0,03, -0,44 ve -1,26 olarak hesaplamıştır. Çalışkan (2015) Du-Pont analiz tekniği ile yapmış olduğu çalışmasında diğer çalışmalara göre farklı sonuçlar bulmuştur. 2009-2013 yılları arasında sırasıyla aktif karlılığı oranını 7,7, 0, 8,4, 8,7 ve 0 olarak hesaplamıştır. Yıllar arası sert düşüşleri net karın sıfır olmasına dayandırmıştır. Yıldız (2013) özel hastanelerin ortalama aktif karlılığı oranını -0,02 olarak hesaplarken, kamu hastanelerinin ortalama oranını $-0,23$ olarak tespit etmiştir.

\section{Araştırmanın Evreni, Örneklemi ve Yöntemi}

Araştırmanın evreni; Hatay Büyükşehir Belediyesi sınırları içinde yer alan Sağlık Bakanlığına bağlı 9 devlet hastanenin 2008-2017 yılları arasındaki bilanço ve gelir tablolarından oluşmaktadır. Araştırmada örneklem çekilmeyerek, 9 devlet hastanesinin tamamı araştırma kapsamına alınmıştır. Analizlerde kullanılan veriler Hatay İl Sağlık Müdürlüğü'nden alınmıştır.

Araştırmanın varsayımı, Sağlık Bakanlı̆̆g'na ait Tek Düzen Muhasebe Sistemi üzerinden elde edilen finansal tablo verilerinin doğru ve eksiksiz olmasıdır.

Araştırmada, arşivlerde 2008 yıldan önceki veriler eksik ve yetersiz olduğundan ve tek düzen hesap planına uygun tutulmadığından 2008-2017 yıllarına ait bilanço ve gelir tabloları kullanılmıştır. Araştırmaya ancak 2008 yılından sonraki veriler dahil edilebilmiştir. Araştırmaya, Hatay Büyükşehir Belediyesi sınırları içerisindeki dört Ağız ve Diş Sağlığı Merkezi'nin bilanço ve gelir tablolarındaki kalemlerin devlet hastanelerinin kalemlerindeki farklılıklardan dolayı ve ayrıca iki devlet hastanesinin 2015 yılı itibariyle kurulması nedeniyle araştırmaya dahil edilmemişlerdir.

02 Kasım 2011 tarihli ve 663 sayılı "Sağlık Bakanlığı ve Bağlı Kuruluşlarının Teşkilat ve Görevleri Hakkında Kanun Hükmünde Kararname" ile Türkiye Kamu Hastaneleri Kurumu ve bu kuruma bağlı İl Kamu Hastane Birliği Genel Sekreterlikleri oluşturulmuştur. Kurumun kuruluş ve İl Kamu Hastane Birlik Genel Sekterliklerinin geçiş süreci 2012 yılında gerçekleştirilmiş, 2013 yılında Sağlık Bakanlığına bağlı bütün hastaneler birlik hastanesi konumuna gelmiştir (www.tkhk.saglik.gov.tr, Erişim: 01.01.2017). Araştırma verisi 2008-2017 yılları arası yılsonu kesin bilanço ve gelir tablolarından elde edilmiştir. Hatay İl Sağlık Müdürlüğü'nden finansal tablolar resmi yazıyla temin edilmiştir. Araştırma verisi kurum yetkilileri tarafından Sağlık Bakanlığı web uygulamaları arasında bulunan TDMS Modülü üzerinden çekilmiş ve kullanılmasına izin verilmiştir.

\section{Bulgular}

Oran analizi kapsamında, 2008-2017 yılları bilanço ve gelir tablolarına ilişkin kalemler üzerinde likidite, finansal yapı, faaliyet ve karlılık oranları grafikler yardımı ile sunulmuştur. 


\subsection{Likidite Durumu}

Hatay İli Sağlık Bakanlığı Hastanelerinin kısa vadeli borç yükümlülüklerini ödeyebilme güçlerini görebilmek için likidite oranlarına bakılmıştır.

\subsubsection{Cari Oran}

Araştırma kapsamındaki hastanelerin mevcut dönen varlıklarının kısa vadeli borçlarını karşılama gücü olan cari oranları, yıllara göre Grafik 1'de gösterilmiştir. Genel olarak bu oranın dalgalı bir azalış trendine sahip olduğu görülmektedir. 2008, 2009 ve 2010 yıllarında cari oranın 2 değerinin üzerinde olduğu ancak 2017 yılına gelindiğinde bu oranın 0,88 gibi düşük bir değere indiği görülmektedir. Bu oranın uluslararası standartlarda kabul oranı 2'dir. Yüksek enflasyonlu ve yeterli fon kaynaklarına sahip olmayan veya gelişmekte olan ülkelerde bu oranın 1-1,5 olması hastanelerin ödeme gücünü emniyet marjı olarak görmektedir. 2008-2010 yılları arası cari oranın 2'nin üstünde seyretmesi hastanelerin alacaklarını kolaylıkla tahsil edebildiğini, stoklarını satıșa dönüștürebildiğini ve böylelikle kısa vadeli borçlarını ödeyebilme gücünün yüksek olduğunu göstermektedir. Ancak cari oranın bu yıllarda 3 değerinde seyretmesi işletme sermayesi yatırımının fazlalığından dolayı bir verimsizlik göstergesi olabilir.

2013 yılı itibariyle Kamu Hastaneleri Birliği sistemine geçildikten sonra bu oranın 2014'te 1,24 ve 2015'te 1,27 değerinde olması dönen varlıklarının kısa vadeli yabancı kaynakları karşılayabildiğini gösterirken 2013, 2016 ve 2017 yıllarındaki değerler kabul edilen standartlar açısından değerlendirildiğinde hastanelerin likidite durumlarının ve işletme sermayesinin yetersiz olduğu dolayısıyla kısa vadeli borçlarını karşılamada güçlükler yaşadıkları anlamına gelmektedir. İşletme sermayesinin negatif değere düşmesi, hastanenin dönen varlıklarını nakde çevirmesi dışında yeni bir kaynak bulunması gerektiğini ifade etmektedir.

Grafik 1: Hatay İli Sağlık Bakanlığı Hastanelerinin Cari Oranları

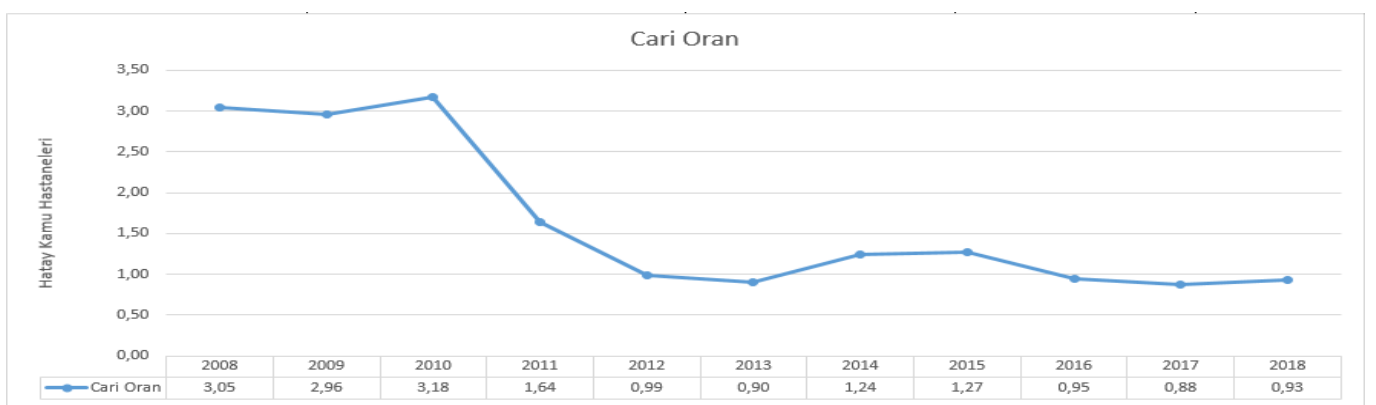

Sonuç olarak kabul edilen standartlara göre sadece cari orana bakarak kıyaslama yapılırsa; hastanelerin kısa vadeli borçları ödeyebilme gücünün yıllar itibari ile düşüş eğiliminde; finansal risklerinin ise yükselme eğiliminde olduğu söylenebilir. Ancak bu düşüş dikkate alınarak likidite göstergelerinin daha hassas olarak analiz edilmesi gerekmektedir. 


\subsubsection{Likidite Oranı (Asit Test Oranı)}

Likitide oranı cari oranı daha da anlamlı kılan net bir ölçümdür. Stoklar hesaba katılmadan hastanelerin nakit ve nakit benzeri değerler ile ödeme gücünü ölçen Grafik 2'deki likidite (asit-test) oranında da Grafik 1'deki gibi aynı yıllar arasında genel bir düşüş eğiliminin olduğu görülmektedir. 2008 yılında 2,63 değerinde olan asit-test oranı 2017 y1lında 0,83 değerine gerilemiştir. Genel ilke olarak likidite oranının en az 1 olması istenir. Likidite oranı Kamu Hastaneleri Birliği sistemine geçiş sürecine kadar yüksek düzeyde azalış trendi gösterirken, 2013 yılından sonra oranların dengelendiği görülmektedir. 2008, 2009, 2010 ve 2011 yıllarında likidite oranının sirasiyla $2,63,2,29,2,63$ ve 1,31 olmasi hastanelerin kısa vadeli ticari borçlarını, ödenecek vergi ve diğer yükümlülüklerini kolaylıkla karşılayabildiğini göstermektedir.

Grafik 2: Hatay İli Sağlık Bakanlığı Hastanelerinin Asit-Test Oranları

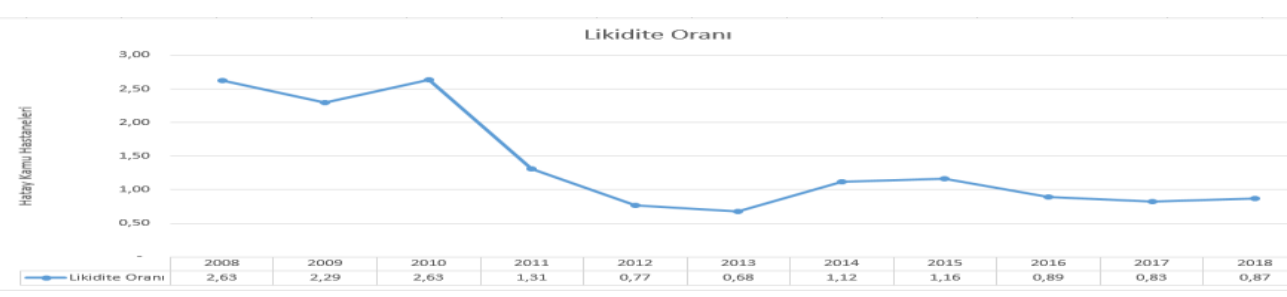

$\mathrm{Bu}$ oranın 1'in altında olması hastanelerin stoklara bağımlılı̆ının fazla olması, hazır değerlerinin dönen varlıklar içindeki payının az olması ve ticari alacaklarının fazla olması kısa vadeli borçlarını ödemekte sıkıntılar yaşadığını gösterse de daha sağlıklı analiz için alacak devir hızı, alacakların ortalama vadesi, peşin satışların toplam satışlar içindeki payı gibi göstergelere dikkat edilmelidir.

\subsubsection{Nakit Oranı}

Nakit oran1, hastanelerin elinde bulundurdukları nakit ve nakit benzeri varlıklarının kısa vadeli borçlara oranını ifade eder. Hastanenin hazır değerleri ve menkul kıymetleri ile kısa vadeli borçlarını karşılama gücünü gösterir. Genel kabul olarak bu oranın 0,20 'den az olmaması istenir. Grafik 3.'e yıllar itibariyle bakıldığında hastanelerin ellerinde genel olarak atıl durumda bulunan bir nakitten bahsedilemez. Ancak 2009, 2014 ve 2015 yıllarındaki nakit oranının sirasıyla 0,34, 0,26 ve 0,33 olması hastanelerin kısa vadeli borçlarını ödemede sıkıntılar yaşamayacağı anlamını taşırken; kalan diğer yıllarda hastanelerin acil para ihtiyacına karşı sıkıntılar yaşayabileceği görülmektedir.

Grafik 3: Hatay İli Sağlık Bakanlı̆̆ı Hastanelerinin Nakit Oranları

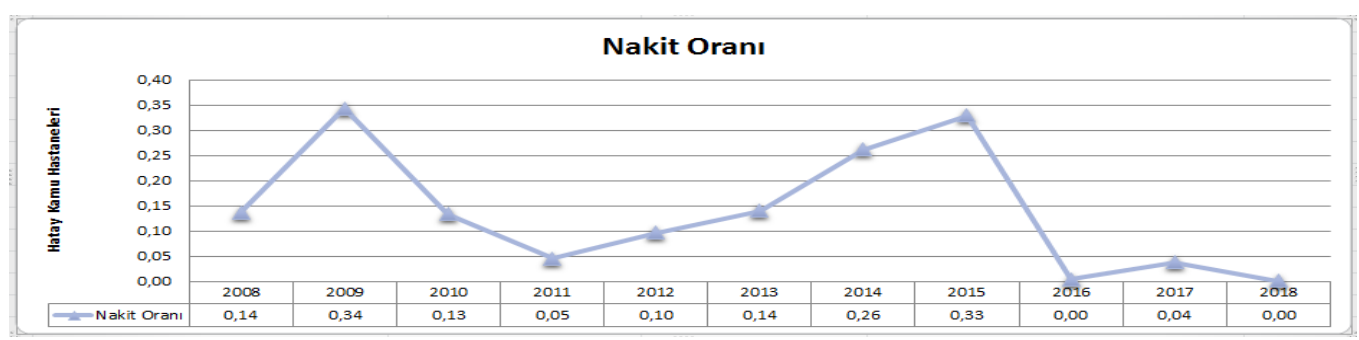




\subsection{Finansal Yapı Oranları}

Hastanelerin kaynak yapısı ile ilgili oranlar, finansal yapı oranları içerisinde değerlendirilmiştir.

\subsubsection{Finansal Kaldıraç Oranı}

Hastanelerin ne ölçüde borca bağımlı olduğunu gösteren kaldıraç oranının \%50'nin üstünde olmaması gelişmiş ülkelerce kabul edilen bir kuraldır. Ancak ülkemizde ve gelişmekte olan ülkelerde bu oranın sonucu özkaynak sağlamadaki zorluklardan dolayı \%60'dan yüksektir.

Grafik 4. incelendiğinde yıllar itibariyle dalgalı bir artış yaşandığ 1 görülmektedir. 2008 ve 2011 yılları arasında finansal kaldıraç oranı genel kabul oranı \%50'nin altında seyretmektedir. 2012 yılından itibaren yükseliş trendine girmiş ve 2017 yılında en yüksek değeri görmüştür. Bu orandaki artış genel olarak hastanelerin borçlarının arttığını ve bu borçların karşılanmasında zorluklar yaşanabileceğini göstermektedir. Kamu Hastaneler Birliği sistemine geçildikten sonra bu oran inişli çıkışlı seyretse de toplam yabancı kaynak tutarının, finansal kaldıraç oranına eş olan tutardan daha yüksek olduğu görülmektedir. Kamu hastanelerinde finansal borçlanma olmadığından uzun vadeli kaynaklar yok sayılmıştır. Mal ve hizmet üreten firmalara (ilaç ve medikal firmalar vb.) olan borçlar kısa vadeli ticari borçlardır. Hastanelerin geçmiş yıllara ait borçları ve özkaynak sağlamadaki güçlükler bu oranın 1'in üstüne çıkmasına neden olmuştur.

Grafik 4: Hatay İli Sağlık Bakanlığı Hastanelerinin Finansal Kaldıraç Oranları

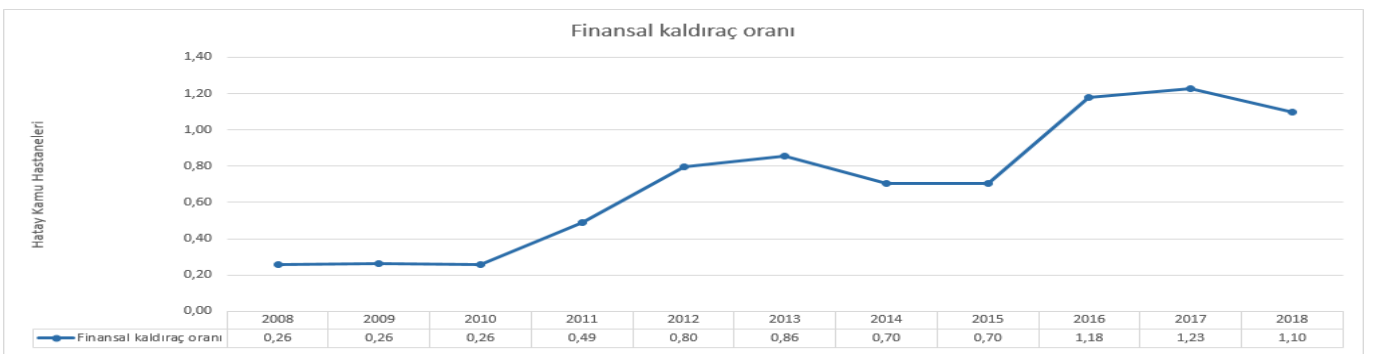

\subsubsection{Toplam Borçlar/ Özkaynaklar}

Finansman oranı olarak da bilinen bu oran işletmenin nasıl finanse edildiğini göstermektedir. Genel kabul oranı 1'dir. Grafik 5.'e bakıldığında hastanelerin özkaynakları 2008, 2009, 2010 ve 2011 yıllarında sirasiyla 0,35, 0,36, 0,35 ve 0,95 değerleriyle toplam borçlarını iki kere ödeyebilme gücüne sahipken; bu oran 2012, 2013, 2014 ve 2015 y1lındaki sirasıyla 3,96, 3,48, 2,06 ve 2,06 değerinde olması bu hastanelerin toplam borçlarının özkaynaklarla karşılanamayacak kadar fazla olduğunu göstermektedir. Ayrıca devam eden yıllarda bu oranın -7,40'lara kadar gerilemesi özkaynakların negatif değerlere düşmesinden kaynaklanmaktadır. 
Grafik 5: Hatay İli Sağlık Bakanlığı Hastanelerinin T.Borç/Özkaynaklar Oranları

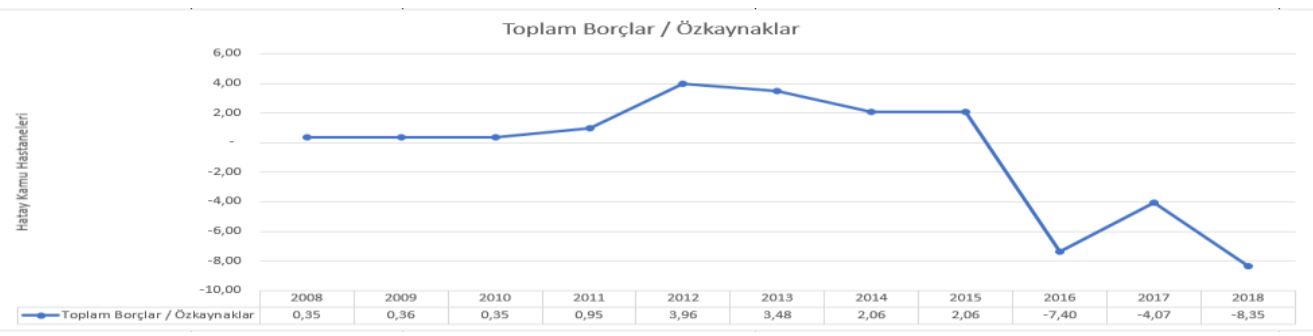

\subsubsection{Net Çalışma Sermayesinin Toplam Aktife Oranı}

Net çalışma sermayesinin (NÇS) toplam aktiflere oranının yüksek olması işletme faaliyetlerinin devamının sağlanmasında etkili olmaktadır. Bu oranın artması işletmenin likidite gücünün göstergesidir. Grafik 6'da görüldüğü gibi hastanelerin bu oranı, 2008 ve 2017 yılları arasında dalgalı bir azalış seyrindedir. 2008 ve 2011 yılları arasındaki pozitif değerler hastanelerin kısa vadeli borçlarını karşılama ve günlük faaliyetlerini devam ettirme konusunda sıkıntılar yaşamamakta olduğunu ancak 2012, 2013, 2016 ve 2017 'deki değerlerin sirasiyla $-0,01,-0,09,-0,05$, ve 0,13 seyrinde olması kısa vadeli borçlarının dönen varlıklardan fazla olmasının bir göstergesidir.

Grafik 6: Hatay İli Sağlık Bakanlığı Hastanelerinin NÇS/T.Aktifler Oranları

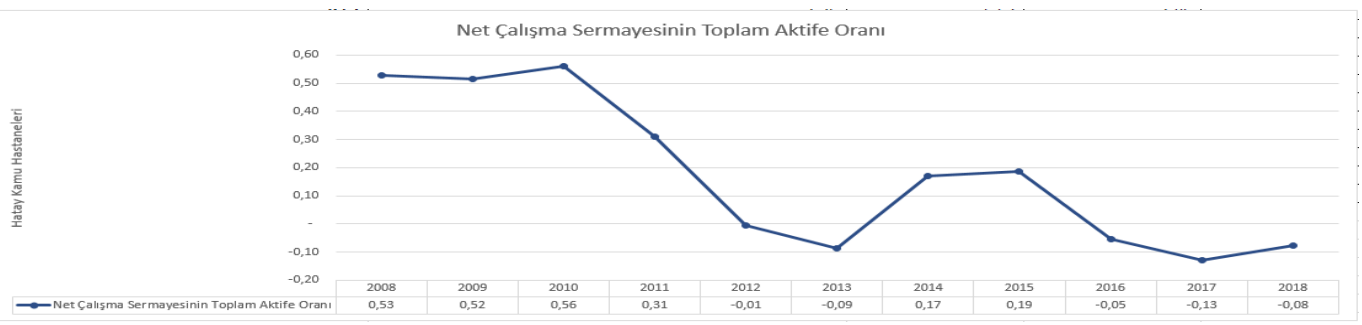

\subsection{4. Özsermaye Çarpanı}

Aktiflerin sermayenin kaç katı olduğunu, başka bir ifadeyle varlıkların ne kadarlık kısmının öz kaynaklardan finanse edildiğini analiz eden bu oranın yüksek olması yüksek kaldıraç kullanıldığını göstermektedir. Genel kabul oranı 2-2,5 değerleri arasındadır. Öz sermaye çarpanı, 2008 ve 2011 yılları arasında sırasıyla 1,35, 1,36, 1,35 ve 1,95 oranlarıyla dengeli seyrederken, 2012 yılındaki 4,96 ile en yüksek seviyesini görmekte olup, 2017 y1lı ve sonrasında negatif yönlü eğilimini sürdürmektedir. 2016 y1lı itibariyle özsermayenin negatif seviyelerde olması nedeniyle bu oranın negatif değerli sonuçlar verdiği görülmektedir. Hastaneler, 2008 yılında toplam aktiflerinin 2/3'ünü özsermayeleri ile finanse ederken, bu oran 2012 yılında 1/5'e gerilemiştir. Başka bir deyişle hastaneler 2012 y1lı itibariyle toplam varlıklarının finansmanını borçlarıyla karşılama yoluna gitmişlerdir. 
Grafik 7: Hatay İli Sağlık Bakanlığı Hastanelerinin Özsermaye Çarpanları

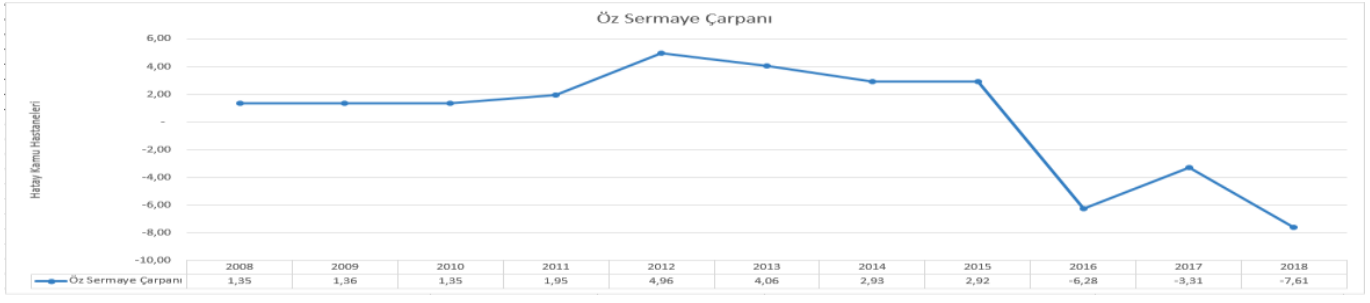

\subsection{Faaliyet Oranları}

Hastanelerin varlıklarını ne kadar etkin kullandıklarını görmek için faaliyet oranlarına bakılmıştır.

\subsubsection{Stok Devir Hızı Oranı}

İşletmelerin stoklarını bir faaliyet döneminde ne kadar etkili ve hızlı tükettiklerini gösteren stok devir hızının yüksek çıkması arzu edilir. Stok devir hızının genel kabul oranı hastanelerde 35 ile 50 arasında olması yeterli görülmektedir. Grafik 8'e bakıldığında yıllar itibariyle dalgalı seyrettiği görülmektedir. 2008-2012 yılları arasında Kamu Hastaneleri Birliği sistemine geçilmeden önce dengeli ve düşük bir şekilde seyreden stok devir hızı oranına bakıldığında stok miktarının ve stok bulundurma maliyetlerinin yüksek olduğu ve stokları elden çıkaramadığı veya nakit paranın stoklara yatırımı söz konusu olduğu söylenebilir. 2013 y1lında Kamu Hastaneleri Birliği sistemine geçişle birlikte stok devir hızı oranı 12,30 değerinden 26,45 değerine doğru artış gösterirken 2017 yılında 54,19 değerinden 32,81'lik değere düşüş göstermesine rağmen 2018 yılında bu oran tekrar yükselerek 35,88 olmuştur. Bu oran genel kabul görülen stok devir hızı oranları arasına girmiştir.

Stok devir hızının bu yıllarda yüksek olması genel olarak hizmet işletmeleri olan hastanelerin, "ilk madde ve malzeme stoklarının malzeme özelliklerinden dolayı belirli seviyelerde olmasl, Să̆llk Bakanliğl hastaneleri arasındaki stokların elektronik olarak izlenerek hastanelerin birbiri ile stok alışverişi yapması, yarı mamül ve mamüller stok kalemlerinin olmamass gibi nedenlerden kaynaklanabilmektedir" (Gazi vd., 2016: 8).

Grafik 8: Hatay İli Sağlık Bakanlığı Hastanelerinin Stok Devir Hızları

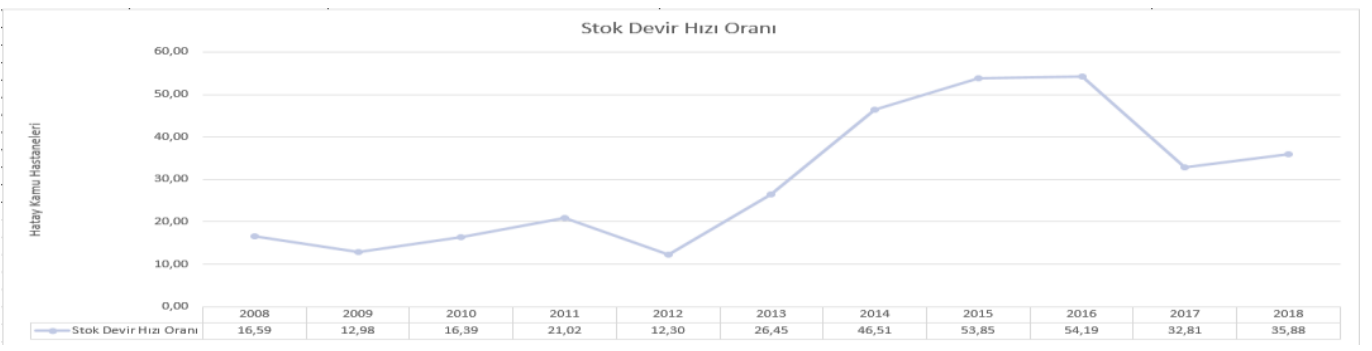




\subsubsection{Dönen Varlıkların Devir Hızı}

Dönen varlıkların devir hızının yüksek olması istenen bir durum olmasına karşın tek başına değerlendirilmemesi gereken bir orandır. Grafik 9'da 2013 yılında görece olarak dönen varlıkların daha etkin kullanıldığı, en düşük devir hızının 2017 yılında 2,01 oranıyla gerçekleştiği görülmektedir. Ancak satış hasılatı olarak 2008 yılından itibaren 2017 yılına kadar dönen varlıkların en az 2 katı kadar satış hasılatı gerçekleştiği ve bunun 2013 yılında 7,72 değeriyle en yüksek noktaya ulaştığı görülmektedir.

Grafik 9: Hatay İli Sağlık Bakanlığı Hastanelerinin Dönen Varlık Devir Hızları

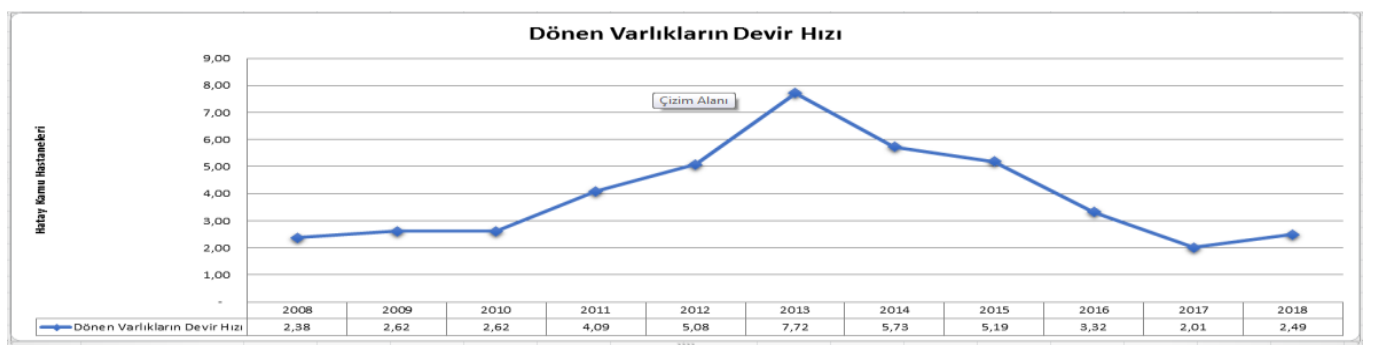

\subsubsection{Duran Varlık Devir Hızı}

Grafik 10'da hastanelerin duran varlık devir hızının 2008-2017 y1lları arasında sürekli bir artış seyrinde olduğu görülmektedir. 2013 yılında Kamu Hastaneleri Birlikleri'ne geçiş itibariyle duran varlıkların daha etkili kullanıldığı söylenebilir. $\mathrm{Bu}$ yıllarda hastanelerin tam kapasite ile çalıştığını söylemek mümkündür.

Grafik 10: Hatay İli Sağlık Bakanlığı Hastanelerinin Duran Varlık Devir Hızları

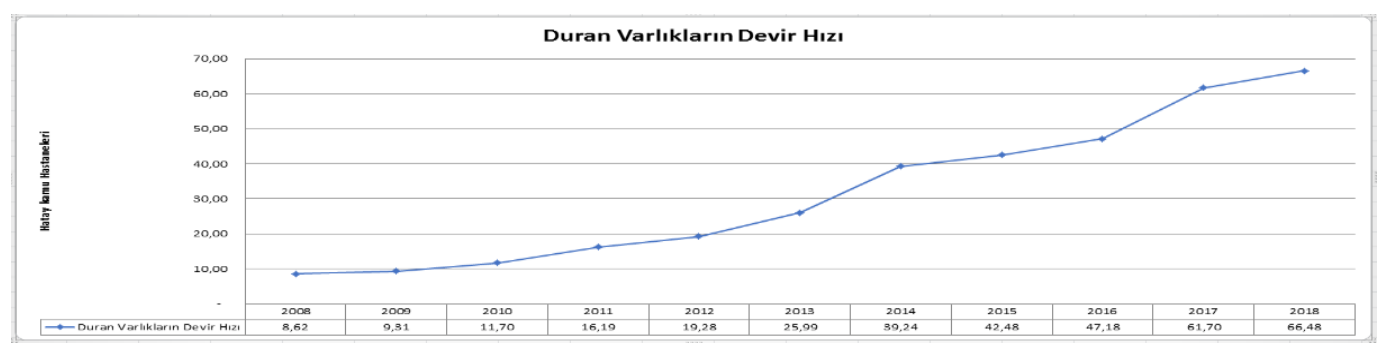

\subsection{4. Özkaynak Devir Hızı}

Özkaynakların etkinliğini ölçmede kullanılan analizlerden birisi de özkaynak devir hızı oranıdır. Bu oranın yüksek çıkması hastanelerin faaliyetlerini borçla finanse ettiği, düşük olması ise daha çok özkaynaklarla finanse ettiği anlamına gelmektedir. Özkaynak verimliliğinde 2008 ve 2011 yılları arasında dengeli küçük artışlar yaşanmış olup, 2012 yılında 19,95 değerine yükselmiş ve en yüksek değerini 2013 yılı itibariyle 24,18 ile göstermektedir. 2013 yılından sonra düşme eğilimi gösteren özkaynak devir hızı 2016 yılı itibariyle hastanelerin geçmiş yıllar zararının oluşması özkaynakların negatif değer almasına neden olmuştur. Dolayısıyla özkaynak devir hızı negatif sonuçlar vermiştir. 
Grafik 11. Hatay İli Sağlık Bakanlığı Hastanelerinin Özkaynak Devir Hızları

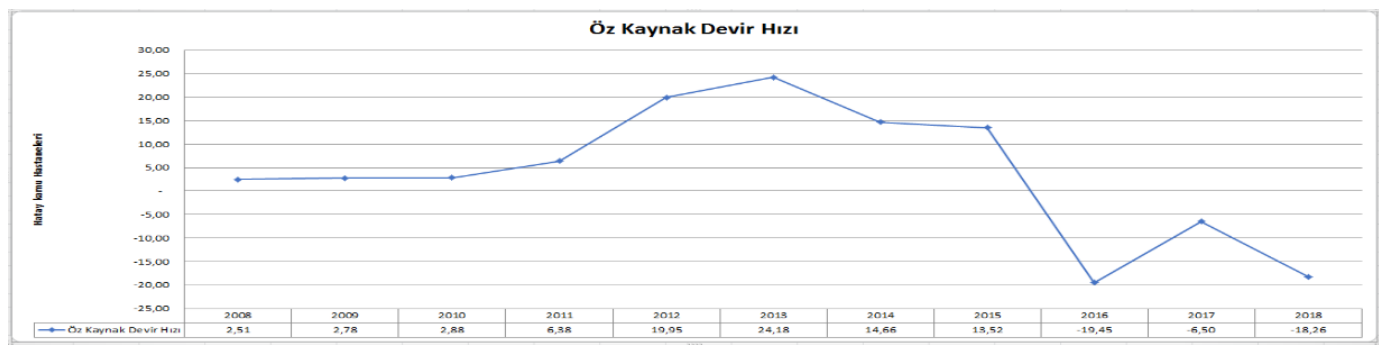

\subsubsection{Aktif Devir Hızı}

İşletmenin dönen ve duran varlıklara yaptığ 1 yatırımların karşılığı olarak varlıklardan tam kapasite verim alınıp alınmadığı hususunda bilgi veren aktif devir hızının yüksek olması istenir. Aktif devir hızının yüksek olması diğer değişkenler sabit tutulduğunda karlılığın da artacağı anlamına gelmektedir. Grafik 12'de hastanelerin 2008 ve 2013 yılları arasında aktif devir hızının arttı̆̆ı, 2014 yılı itibariyle 2017 yılına kadar küçük bir azalış trendine girdiği görülmektedir. 2013 yılındaki 5,95 değeri aktif devir hızının en yüksek olduğu seviye olarak görünmektedir.

Grafik 12: Hatay İli Sağlık Bakanlığı Hastanelerinin Aktif Devir Hızları

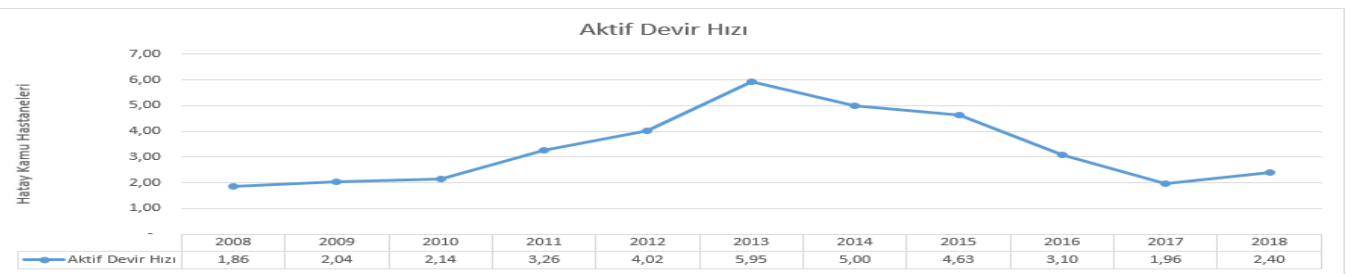

İşletmelerin toplam varlıkları arasında duran varlıkların dönen varlıklara göre nispeten önemsiz olması aktif devir hızının yüksek çıkmasına neden olabilmektedir.

\subsubsection{Net Çalışma Sermayesi Devir Hızı}

Net çalışma sermayesi devir hızı, net satışların ortalama net çalışma sermayesine bölünmesi ile bulunur. Bulunan sonuç net çalışma sermayesi aracılığıyla ne oranda satış yapıldığını gösterir. Grafik 13'de 2008 ile 2012 yılları arasında dengeli bir şekilde artış gösteren bu oran net çalışma sermayesinin etkin kullanıldığının bir göstergesidir. 2008 ve 2017 yılları arasında net satışlar devamlı artış göstermesine rağmen net çalışma sermayesinde 2013 yılı itibariyle negatif yönlü düşüş, 2014 ile 2015 yıllarındaki artışın 2016 yılına yansımasıyla net çalışma sermayesi devir hızının dalgalı bir seyir izlemesine neden olmuştur. Hastanelerin 2013 ve 2017 yıllarında net işletme sermayelerini etkili bir şekilde kullanmadıkları söylenebilir. 
Grafik 13: Hatay İli Sağlık Bakanlığı Hastanelerinin NÇS Devir Hızları

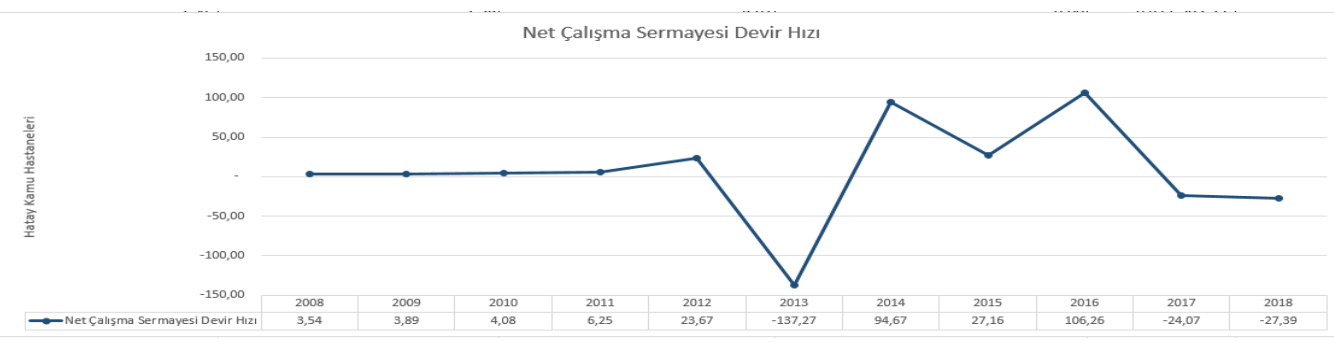

\subsubsection{Alacak Devir Hizı}

Alacaklarını paraya dönüştürebilme hızını ölçen alacak devir hızı (ADH), net satışların ortalama ticari alacaklara bölünmesi ile hesaplanmıştır. 2008 ve 2017 yılları arasında ADH'nda dalgalı artış ve azalışlar görünmektedir. 2008 yılında 6,67 olan bu oran 2012 yılına kadar dengeli seyretse de Kamu Hastane Birlikleri'nin tamamen oluşturulduğu 2013 yılında 11,21, 2014 yılında 11,41 ve 2015 y1lında 10,12'lik bir oranda yüksek artış yaşamıştır.

Grafik 14: Hatay İli Sağlık Bakanlığı Hastanelerinin Alacak Devir Hızları

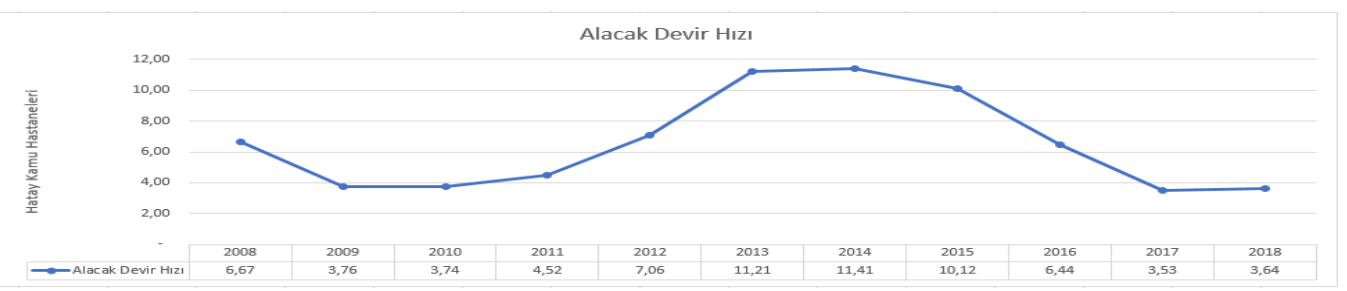

\subsubsection{Ticari Borçların Devir Hızı}

İşletmenin bir yılda borçlarını ödeme sıklığı hakkında değerlendirmelerde bulunabilmek için kullanılan bu oranın düşük çıkması işletmenin likidite sıkıntısı yaşamadığının ve borçlarını uzun vadeye yaydığının göstergesidir. Grafik $15^{\text {' de }}$ 2008-2017 yılları arasında ticari borç devir hızının dalgalı bir seyir izlediği görülmektedir. En düşük oran 4,98 ile 2012 y1lında görülürken, en yüksek oran 2008 yılında 22,53 ile görülmüştür. Borçların devir hızı düştükçe borçların ödeme süresi uzamaktadır. Dolayısıyla hastanelerin son yıllarda borçlarını ödeme süresi uzamaktadir.

Grafik 15: Hatay İli Sağlık Bakanlığg Hastanelerinin Ticari Borçlar Devir Hızları

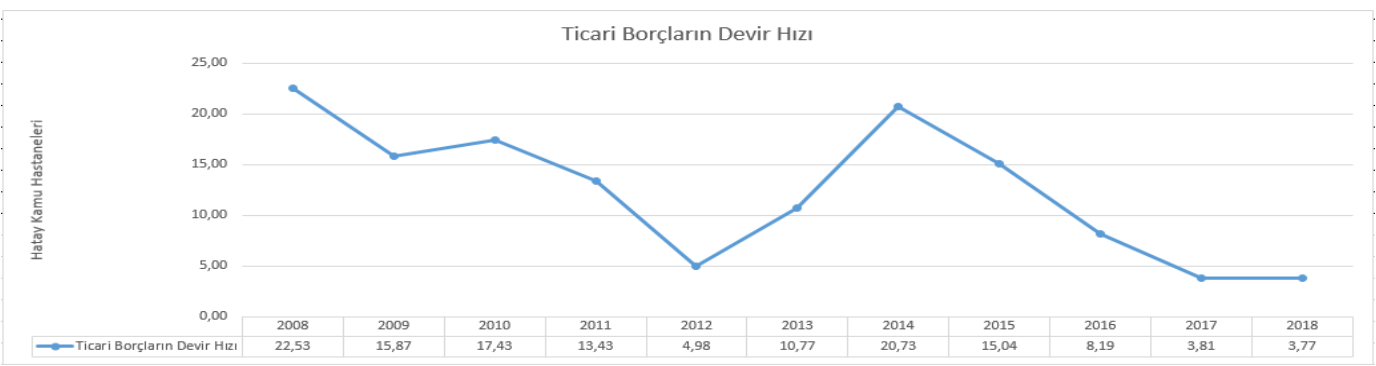




\subsubsection{Alacakların Ortalama Tahsil Süresi ve Ticari Borçların Ödenme Süresi}

Grafik 16'da görüldüğü gibi 2008 ve 2017 yılları boyunca hastanelerin alacakların ortalama tahsil süresi (AOTS) 54 günden 101 güne çıkmıştır. Ticari borçları ödeme süresi (TBÖS) ise bu yıllar arasında 15,98 günden 95 güne kadar yükselmiştir. 2012 yılına kadar bu hastanelerin AOTS, TBÖS'nden daha yüksek olduğu 2012 yılından sonra ise AOTS ile TBÖS'nin dengeli azalış ve artış yaşadıkları izlenmektedir. Başka bir deyişle AOTS uzadığında TBÖS de uzamaktadır. AOTS'nin uzaması ticari borçların ödenmesini geciktirebileceği gibi likidite oranlarının zayıflayacağı ve nakit güçlüğü yaşanabileceği anlamını taşımaktadır. Kamu hastanelerinin AOTS ve TBÖS oranlarının uzaması veya kısalması doğrudan Sosyal Güvenlik Kurumu ile Sağlık Bakanlığı arasındaki global bütçe uygulamasına bağlıdır.

Grafik 16: Hatay İli Să̆lık Bakanlığı Hastanelerinin AOTS ve TBÖ Süreleri

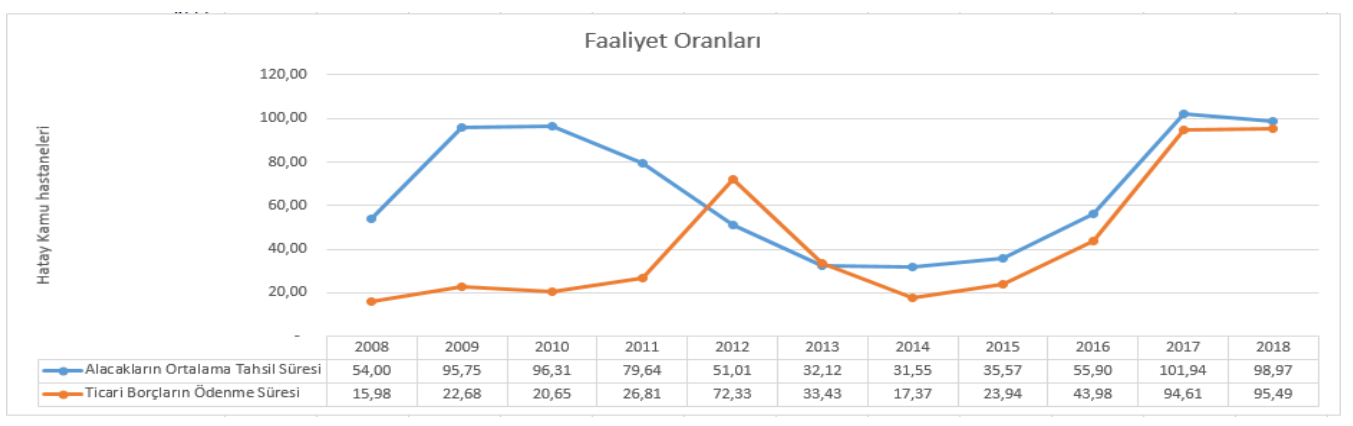

\subsection{Karlılık Oranları}

Hastanelerin karlılık durumları farklı karlılık göstergeleri dikkate alınarak değerlendirilmiştir.

\subsection{1. Özkaynak Karlılığı Oranı}

Dönem net karının özkaynaklara bölünmesi ile bulunan özkaynak karlılığı, daha önceki negatif değerler alan özkaynaklardan ve dönem net zararlardan etkilenebilmektedir. Grafik 17'de özkaynak karlılığı oranı 2008 ve 2013 yılları arasında 0 civarında ve altında değer gösterirken Kamu Hastaneleri Birliği sistemine geçildikten sonra yükseliş trendine girmiş ve 2017 yılından sonra düşüş yaşanmıştır. $\mathrm{Bu}$ yıllar arasında hastanelerde finansal riskin olmadığı ve zarar etmediği anlaşılmaktadır. 2008 ve 2013 yılları arasında hastanelerin sahip oldukları kaynakları iyi değerlendiremedikleri ve gider gerçekleştirme yönetiminde sorunlar yaşandığı görülmektedir. Kamu hastanelerinin özkaynak karlılığı analizinde oranların yüksek çıkmaması her yılsonunda alacaklarının terkin yöntemiyle meydana gelen giderlerin olduğu söylenebilir. 
Grafik 17: Hatay İli Sağlık Bakanlığı Hastanelerinin Özkaynak Karlılık Oranları

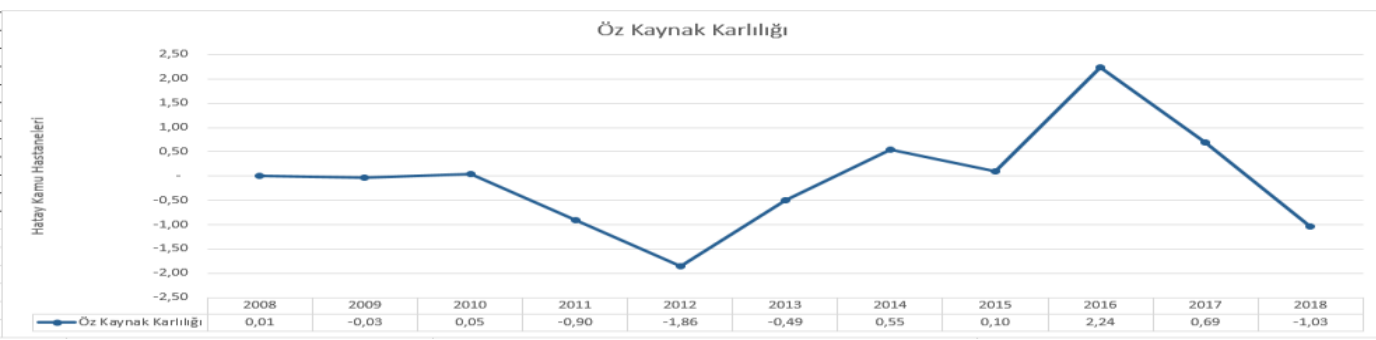

\subsubsection{Brüt Satış Karlılığı}

Net satışlardan satılan malın maliyetinin çıkartılması ile elde edilen sonucun net satışlara oranlanması ile brüt satış karlılığı (BSK) bulunur. Grafik 18'de görüldüğü gibi yapılan analizler sonucunda 2008 yılında 0,04 değerinde BSK'na ulaşan hastanelerin 2009, 2010 ve 2011 yillarında sirasiyla $-0,11 ;-0,07$ ve $-0,04$ oranlarına gerilemesine rağmen 2012 yılında 0,45 değerinde yüksek oranda BSK elde etmiştir. $\mathrm{Bu}$ oran sonraki yıllarda dengeli bir şekilde gerilemiştir. 2012 yılının yüksek BSK incelendiğinde satışların maliyetinin bir önceki ve bir sonraki yıla göre yaklaşık olarak yarı yarıya azaldığı ve bu durumun karlılığa yansıdığı söylenebilir.

Grafik 18: Hatay İli Sağlık Bakanlığı Hastanelerinin Brüt Satış Karlılık Oranları

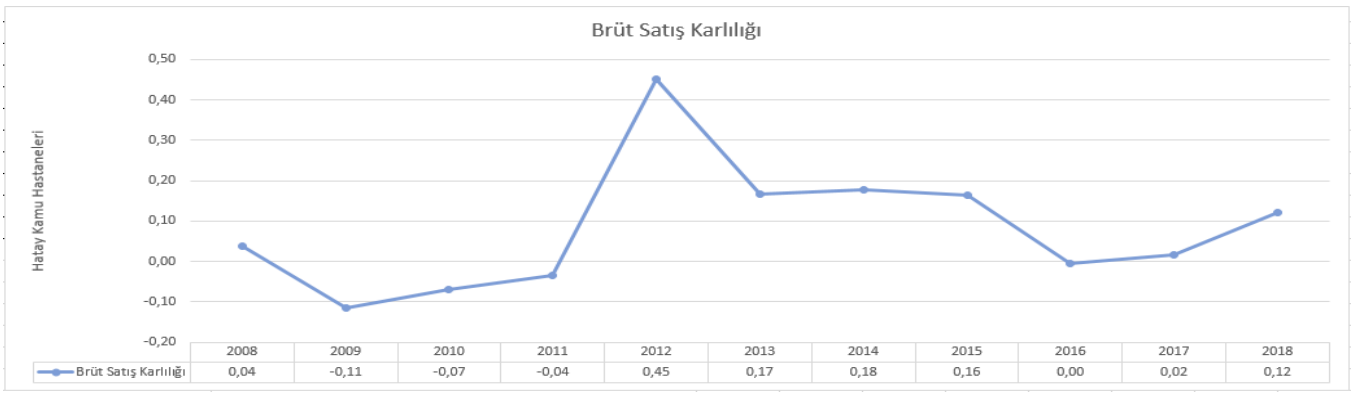

\subsubsection{Net Satış Karlılığı}

Net satış karlılığı oranı Grafik 19'da incelendiğinde; 2010, 2014 ve 2015 yıllarında küçük çapta yükselişler gösterdiğinden bu hastanelerin zarar etmediklerini, ancak 2008 ve 2017 yılları arasında genel olarak değerlendirildiğinde hastanelerin önemli derecede dönem net karı elde edemediği hatta zarar ettikleri görülmektedir. 2011, 2016 ve 2017 yıllarındaki sırasıyla $-0,14,-0,12$ ve $-0,11$ değerlerindeki yüksek oranlarda net zararlar incelendiğinde bu durumun faaliyet giderlerinden kaynaklandığı söylenebilir. 
Grafik 19: Hatay İli Sağlık Bakanlığı Hastanelerinin Net Satış Karlılık Oranları

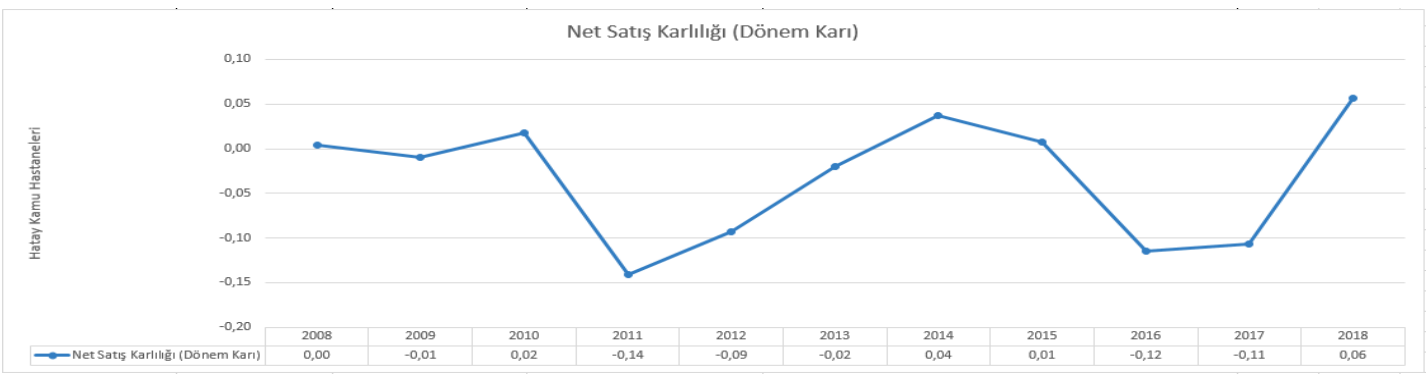

\subsubsection{Aktif Karlılığı}

Aktif karlılığ işletmenin faaliyetlerinde varlıkların ne derecede etkin kullanıldığını gösteren oran olup yüksek çıkması istenir. Grafik 20'de görüldüğü gibi araştırma kapsamındaki hastanelerin 2008 ve 2017 yılları arasında aktif karlılığı oranı yüksek düzeyde dalgalı bir seyir izlemiştir. 2008 y1lında bu oran 0,01 iken 2009'da negatif yönlü 0,02 değerine düşmüş, 2010' da 0,04 değerine yükselen bu oran 2011 yılında negatif derecede 0,46'lara gerilemiştir. En yüksek aktif karlılık 2014 yılında 0,19 olarak görülürken, en düşük aktif karlılık 2011 yılında negatif derecede 0,46'dır. Birbirini izleyen yıllarda aktif toplamlarının genel olarak devamlı artışına rağmen aktif karlılığın dalgalı bir şekilde düşüş veya artış göstermesinin sebebi hastanelerin net karlarındaki düşüşlerden kaynaklanmaktadır. Genel olarak aktif karlılığın 0 civarında ve altında değer alması hastanelerin varlıklarını etkin kullanamadıkları ve zarar etme eğilimlerinde olduklarını göstermektedir.

Grafik 20: Hatay İli Sağlık Bakanlığı Hastanelerinin Aktif Karlılık Oranları

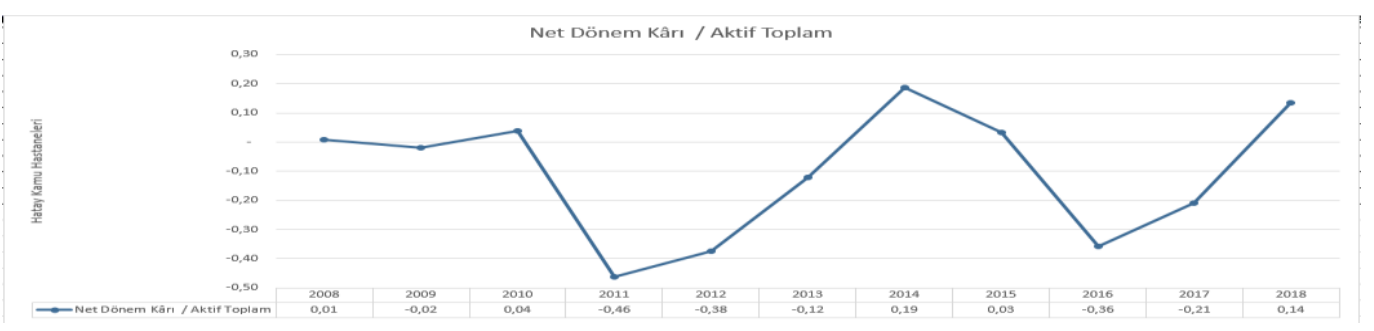

\section{Sonuç Öneriler}

Sürekli gelişim gösteren sağlık sektöründe kamu hastanelerinin birincil amaçları topluma sağlık hizmeti ulaştırmak olsa da meydana gelen değişimlere ayak uydurabilmek, diğer hizmet sunucularına karşı rekabet edebilmek ve gelecek ile ilgili planlamalar yapabilmek için güçlü bir finansal yapıya sahip olmaları gerekmektedir.

Hatay Büyükşehir Belediye sınırları içerisinde yer alan Sağlık Bakanlığına bağlı 9 devlet hastanesinin 2008-2017 yılları arasındaki finansal verilerinden yararlanarak hastanelerin kamu hastane birliklerine bağlanmadan önceki ve bağlandıktan sonraki finansal performansları arasında bir fark olup olmadığını araştıran bu çalışmada yapılan oran analizi çerçevesinde aşağıdaki sonuçlara ulaşılmıştır: 
- İncelenen araştırma kapsamındaki hastanelerin kısa vadeli yükümlülüklerini karşılayabilme güçlerinin yeterli olmadığ ticari alacaklarının tahsilatına bağlı olduğu görülmektedir.

- 2012 yılından itibaren hastanelerin özkaynaklarının yetersiz olduğu ve borçla finanse edildikleri görülmektedir. Kamu hastanelerinde finansal borçlanma olmayıp, faaliyet giderlerini oluşturan ticari borçların olduğunu ve ticari borçların ilaç ve medikal firmalara olan borçlar olduğunu söylemek mümkündür. Hastanelerin bilançolarında kıdem tazminatlar karşılığı hesabı uzun vadeli yabancı kaynaklar kaleminde işlem görmüştür. Dolayısıyla hastanelerin uzun vadeli kaynak kullanımı bulunmamaktadır. Hastanelerin duran varlıklarının finansmanında da kısa vadeli yabancı kaynak kullandığı görülmektedir. Ancak genel bütçe bilgileri çalışma kapsamı dışında tutulduğundan duran varlık yatırımları ile ilgili değerlendirmeler eksik kalmaktadır. Dönen varlıklara fazla yatırım yapıldığında net çalışma sermayesinin etkin kullanılamadığı görülmüştür.

- $\quad$ Faaliyet oranlarından stok devir hızı, net çalışma sermayesi devir hızı ve alacak devir hızı genel olarak 2013 yılından sonra artış göstermiştir. Ancak karlılığın düşük olduğu görüşmüştür. Kamu hastaneleri kar etmemelerine karşın borçlarını kamu desteğiyle uzun vade de olsa ödeyebilmektedirler. Hastanelerin çalışma sermayesi artırımına gidemedikleri bilinmektedir. Bu durum özkaynakların negatif değer almasından kaynaklanmaktadır.

- Hastanelerin faaliyetleri sonucunda genel olarak kar elde edemedikleri ancak yapısal değişiklikler sonucunda faaliyet giderlerinde ve dönem net zararlarında iyileşmelerin yaşandığı görülmektedir.

- $\quad$ Genel olarak Hatay İlindeki devlet hastanelerinin Kamu Hastaneler Birliği dönemi sonrasında beklenen finansal başarıyı sağlayamadıkları görülmüştür.

$\mathrm{Bu}$ sonuçlar doğrultusunda hastane yönetimlerine aşağıdaki öneriler yapılabilir:

- Hastanelerin finansal performanslarını iyileştirmeleri, bunun için de kaliteden ödün vermeden lüks ve israftan uzak durarak faaliyetlerini sürdürmeleri gerekmektedir.

- $\quad$ Giderek artan likidite sıkıntısını engellemek ve karlılığı arttırıcı uygun stratejiler belirlemek.

- Çalışma sermayesi unsurlarının etkili bir şekilde yönetilmesi sağlamak.

- Kamu hastaneleri kar amacı gütmeseler bile özel hastaneler gibi satışlarını artırmak ve katlanılan maliyetleri azaltmak için etkili yöntemler geliştirmelidir.

- $\quad$ Diğer faaliyet giderlerine göre maliyeti yüksek olan duran varlık yatırımları özkaynaklarla finanse edilmelidir.

- Bazı hastaneler bazı dönemlerde zarar etmeseler de geçmiş dönem zararlarının yüksek olmasından dolayı özkaynaklarının negatif değerlere düştüğü görülmektedir. Borç ile özkaynak finansmanı dengelenmeli, özkaynakları attırıcı çalışmalar yapılmalıdır.

- $\quad$ Sağlık Bakanlığı alacak yönetimi konusunda politikalar üretmelidir.

- $\quad$ Gerçekçi ve ekonomik şartlara göre fiyatlar belirlenmelidir. 
- $\quad$ İlaç ve malzeme alım giderlerinin azaltılması sağlanmalıdır.

- Hizmet alımlarının maliyet ve verimlilik takibi yapılmalıdır.

- Hastane yöneticilerinin finansal performans ölçümünün önemini kavramaları, finansal raporlama, analize önem vermeleri ve bu alanda yetkin personel istihdam etmeleri gerekmektedir.

- $\quad$ Sağlık Bakanlığı hastanelerinin finansal analizini yapacak araştırmacıların daha fazla yılı ve hastaneyi kapsayarak çalışma yapması sorunların tespitine ve azaltılmasına katkı sağlayacaktır.

\section{Kaynakça}

Akça, N. ve İkinci, S. S. (2014). Ankara'da Yer Alan Özel Bir Sağlık İşletmesinin Finansal Tablolarının Oran Analizi Yöntemi ile Değerlendirilmesi. Issletme Bilimi Dergisi, 2(1), 111-126.

Akdemir, E. ve Dayı, F. (2013). Sağlık İşletmelerinde Finansal Risk Analizi: Kastamonu Kamu Hastaneleri Örneği. Düzce Üniversitesi Yönetim ve Ĕ̆itim Bilimleri Dergisi, 1-18.

Alparslan, D. (2014). Sağllk Bakanlı̆̆ Hastanelerinde İşletme Sermayesi ile Finansal Performans Göstergelerinin Analizi. Doktora Tezi, Süleyman Demirel Üniversitesi, Sosyal Bilimler Enstitüsü, Isparta.

Ateş, Ç. (2014). Sağllk Işsletmelerinde Finansal Performansın Değerlendirilmesi: Diyarbakır Gazi Yaşargil Ĕgitim ve Araştırma Hastanesi Örneği, Yüksek Lisans Tezi, Beykent Üniversitesi, Sosyal Bilimler Enstitüsü, İstanbul.

Avcı K. (2014) Bir Eğitim ve Araştırma Hastanesinin Finansal ve Operasyonel Performans Göstergeleri Arasındaki İlişki. Hacettepe Sağllk İdaresi Dergisi, 17(1), 1-20.

Aydemir, İ. (2018). Hastanelerde Finansal Performansın Değerlendirilmesi: Türkiye Cumhuriyeti Merkez Bankası Hastane Hizmetleri Sektör Bilançolarında Bir Uygulama. Uluslararası Să̆lı Yönetimi ve Stratejileri Araştırma Dergisi, 4(2), 133-149.

Bıçakçı, H., Ağırbaş, İ., Bülüç, F. ve Turgut, M. (2018). Özel Hastanelerde Finansal Analiz. III. Uluslararası Al- Farabi Sosyal Bilimler Kongresi, Tam Metin Kitab1, 782-787.

Bülüç, F., Özkan, O. ve Ağırbaş, İ. (2017). Oran Analizi Yöntemiyle Özel Hastane Finansal Performansının Değerlendirilmesi, International Journal of Academic Value Studies, 3(11), 64-72.

Çalışkan, S. (2015). Kamu Hastanelerinde Du Pont Analizi ile Finansal Performans Değerlendirilmesi ve Bir Uygulama, Yüksek Lisans Tezi, Eskişehir Osman Gazi Üniversitesi, Sosyal Bilimler Enstitüsü, Eskişehir. 
Çam, H. (2008). Sağlık İşletmelerinde Finansal Performansın Değerlendirilmesi: Karaman Devlet Hastanesi Örneği, Selçuk Üniversitesi, Sosyal Bilimler Enstitüsü, Konya.

Gazi, A., Sonğur, C., Kar, A., Top, M. ve Babacan, A. (2016). Türkiye Kamu Hastane Birlikleri Hastanelerinin Finansal Performanslarının Değerlendirilmesi: Finansal Tablo Analizleri. Journal of Turkish Court of Accounts/Saylştay Dergisi, (100), 1-26.

Güney S. ve Korkmaz M. (2013). Hastanelerde Mali Performansin İncelenmesi: Ümraniye Araştırma ve Uygulama Hastanesi Üzerine Örnek Bir Uygulama. Karadeniz Blacksea Chornoye More Dergisi, 17(17), 148-164.

Islıcık, S. (2018). Sağllk İsletmelerinde Finansal Performans Analizi ve Isşetme Sermayesi Ilişskisi: Türkiye Kamu Hastanelerine Yönelik Bir Uygulama. Yüksek Lisans Tezi, Gazi Üniversitesi Sosyal Bilimler Enstitüsü, Ankara.

Karadeniz, E. (2016). Hastane Hizmetleri Alt Sektörünün Finansal Performansının Incelenmesi: Türkiye Cumhuriyeti Merkez Bankası Sektör Bilançolarında Bir Uygulama, Hacettepe Sağlık İdaresi Dergisi, 19(2), 103-104-110.

Kırbaş, H. (2010). Hastane İşletmelerinde Çalışma Sermayesi Yönetimi: Antalya ili Sağlık Bakanlığına Bă̆lı Kamu Hastanelerinin Çalışma Sermayesi Etkinliklerinin İncelenmesi. Yüksek Lisans Tezi, Akdeniz Üniversitesi, Sosyal Bilimler Enstitüsü, Antalya.

Koçyiğit, S. Ç. ve Kocakoç, N. (2019). Ankara İli Kamu Hastanelerinin 2008-2017 Dönemi Finansal Performans Analizi. Journal of Business Research-Turk/ IŞletme Araştırmaları Dergisi, 11(2), 1280-1293.

Orak, S. (2015), Ankara İli Să̆llk Bakanlı̆̆ı Hastanelerinin 2008-2013 Dönemi Finansal Performansının Oran Analizi ile Incelenmesi, Yayınlanmamış Yüksek Lisans Tezi, Hacettepe Üniversitesi, Sosyal Bilimler Enstitüsü, Ankara.

Özgülbaş, N. (2001). Hastanelerde Teknik ve Finansal Performans İlişkisi, Yayınlanmamış Doktora Tezi, Hacettepe Üniversitesi, Ankara.

Özgülbaş, N., Bayram, A. (2002). Hastanelerin Finansal Başarısızlığında Çalışma Sermayesi Yönetiminin Rolünün Tespiti: Sağlık Bakanlığı Hastanelerinde Bir Uygulama. 5. Ulusal Sağlık ve Hastane Yönetimi Sempozyumu, Eskişehir, 1619.

Özgülbaş, N. (2006). Türkiye'de Kamu Hastanelerinin Finansal Durum Değerlendirmede Kullanabilecekleri Bir Yöntem: Trend Analizi. Muhasebe ve Finansman Dergisi, 29, 129-139.

Palamutçu, S. (2013). Kamu ve Özel Sağlık Işletmelerinde Finansal Performansın Oran Analizi ile Ölçülmesi ve Karşılaştırılması. Yüksek Lisans Tezi, Beykent Üniversitesi Sosyal Bilimler Enstitüsü, İstanbul. 
Pay, M. (2017). Kamu Hastane Kurumlarl Sisteminin Finansal Performans Açısından Değerlendirilmesi. Yüksek Lisans Tezi, Dokuz Eylül Üniversitesi, Sosyal Bilimler Enstitüsü, İzmir.

Tarcan, M. (2006). Hastanelerde Finansal Performansl Etkileyen Etmenlerin Belirlenmesi: Să̆lık Bakanlı̆̆l Hastanelerinde Çok Değişkenli Bir Analiz. Yayınlanmamış Doktora Tezi, Hacettepe Üniversitesi, Sağlık Bilimleri Enstitüsü, Ankara.

www.tkhk.saglik.gov.tr, (Erişim: 01.01.2017).

Yıldız, B. (2013). Sağlık İşletmelerinde Finansal Performansı Etkileyen Unsurlar ve Finansal Performansın Ölçülmesi: Hastanelerde Bir Uygulama. Doktora Tezi, Atatürk Üniversitesi, Sosyal Bilimler Enstitüsü, Erzurum. 